\title{
MUTUAL SUPPORT IN COMMUNITY DEVELOPMENT FOR EARTHQUAKE RECONSTRUCTION IN ACEH BESAR, INDONESIA
}

\author{
Kazuko Tatsumi ${ }^{*}$, Zulhamsyah Imran $^{2}$, Masahiro Yamao ${ }^{3}$ \\ ${ }^{1}$ Faculty of Economics, Fukuoka University, Fukuoka, Japan \\ ${ }^{2}$ IPB University and Southeast Asian Regional Centre for Tropical Biology, Bogor, Indonesia \\ ${ }^{3}$ Graduate School of Biosphere Science, Hiroshima University, Hiroshima, Japan \\ *Corresponding author: E-mail: ktatsumi@fukuoka-u.ac.jp
}

Citation: Tatsumi, T., Imran, Z., Yamao, M. 2020. Mutual Support In Community Development For Earthquake Reconstruction In Aceh Besar District, Indonesia. J. Asian Rur. Stud. 4(2): 119137

\begin{abstract}
On December 26, 2004, the Indian Ocean earthquake, which had its epicenter off the northern coast of Sumatra, was followed by a series of huge tsunami waves, which caused considerable damage to many coastal communities in Asia. In Indonesia, Aceh and North Sumatra suffered the greatest. Many residents rapidly lost their families, homes, fishing boats, farmland, well-being, and self-confidence. Numerous donors provided considerable support, and many victims gradually recovered. Through these tremendous efforts, the victims have gradually regained their well-being; in the over fifteen years since the tsunami, reconstruction has resulted in sustainable community development. This study aimed to determine how the victims have rebuilt their livelihoods and how communities have supported them. The fieldwork comprised interviews with key members of affected local communities in Aceh Besar District in 2006-2018. Some respondents were selected for interview and focus group discussions. This study examines the recovery process, how victims developed social relations, and how they were encouraged and developed self-confidence and independence. The results showed that for the victims, the most important factors in the reconstruction were (1) a firm relationship with family and relatives and (2) a strong sense of community. This study found that women's activities were supported by Panglima Laot Lhok (fishing communities' leaders), Toke Bangku (financial traders), and a fish processing association. Those actors were important for the economic, financial, and social institutions in the community. Mutual support in the community and indigenous institutions played roles in strengthening social resilience. The incomegenerating activities in the mutual system empowered victims - especially women - and their families. The victims developed a feeling of self-confidence and independence that has gradually increased. Through community-based activities, the victims improved their livelihoods.
\end{abstract}

Keywords: Mutual Support; Community-Based; Indigenous Institutions; Community Development; Earthquake Reconstruction

\section{Introduction}

In Aceh Province, the final report of Rehabilitation and Reconstruction Agency for Aceh and Nias (BRR-Badan Rehabilitasi dan Rekonstruksi NAD-Nias) estimated that this tragedy resulted in 126,741 deaths, 93,285 missing people, and 750,000 people losing their livelihoods. For all ages, females were 1.44 times more likely to die than 
males (BRR NAD-Nias, 2009a). Emergency and recovery action were taken by the Indonesian government and many donors around the world.

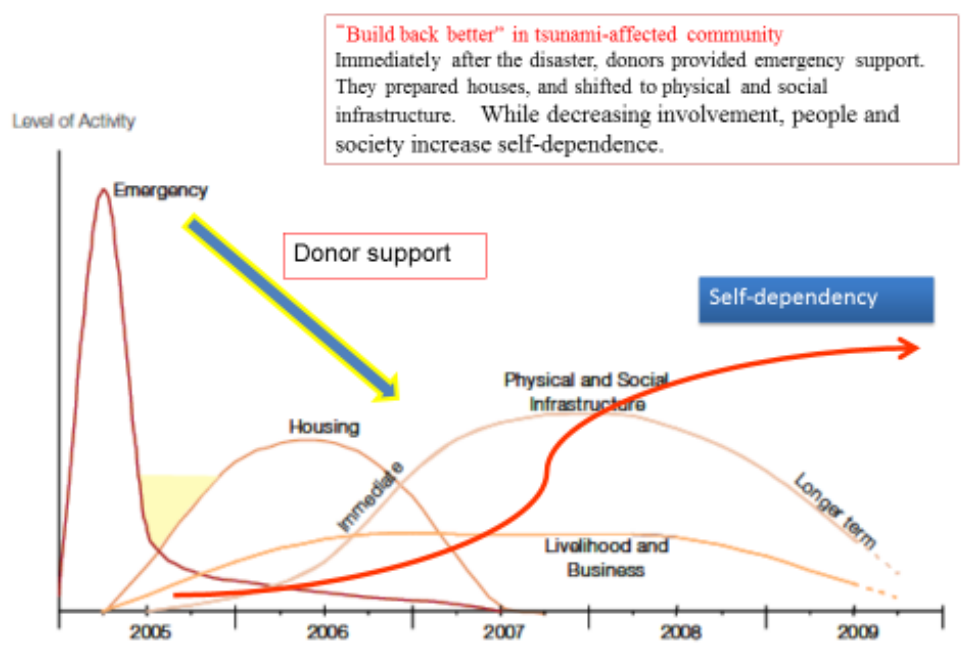

Figure 1. Recovery Process: Livelihood Improvement and Development of Social Capital Source: Yamao (2011) referring to the Rehabilitation and Reconstruction Agency (BRR and International Partners, 2005).

As illustrated in Figure 1, emergency support was provided to build back better in the first stage of relief efforts following the tsunami. In the second stage, temporary housing and reconstruction of permanent houses was initiated within the area affected by the disaster. In the final stage, development of physical and social infrastructure was undertaken: donor agencies undertook enormous efforts to support microfinance programs through technical assistance and capacity-building programs. Throughout the entire area of tsunami-affected coastal communities, countless microfinance groups were established-especially for women. That substantial support for incomegenerating activities gradually helped promote the victims' self-reliance.

Most projects that addressed women's recovery aimed to operate over short periods of time and were unsustainable. That development was unavoidable: most funding schemes were designed for short-term projects; the average project duration was under 2 years. In the case of livelihood recovery efforts affecting women, most businesses operated by women were very vulnerable in the first stage of relief efforts, and they failed, as well lost their capital and had to raise new capital.

In light of this situation, the present study aimed to determine how female victims rebuilt their livelihoods and how communities supported them. This study examines the recovery process, how female victims developed social relations, and how they were encouraged and developed self-confidence and independence through project-based and community-based endeavors. Those projects had some limitations. Generally, many victims were gradually able to recover by the third stage of relief efforts. Thanks to the tremendous efforts made, the victims have slowly regained their sense of well-being; over fifteen years after the disaster, the reconstruction is considered an example of 
sustainable community development. This study emphasizes the importance of community support.

There are several reasons for this study being an interesting case of livelihood recovery. Communities commonly have various capacities for increasing their resilience. Tobin (1999), Béné et al. (2012), Obrist et al. (2011), and Keck (2012) suggested that there are three types of capacities for social resilience: coping, adaptive, and transformative (Table 1):

Table 1. Three Capacities of Social Resilience

\begin{tabular}{|c|c|c|c|}
\hline & $\begin{array}{c}\text { Coping } \\
\text { capacities }\end{array}$ & $\begin{array}{l}\text { Adaptive } \\
\text { capacities }\end{array}$ & $\begin{array}{l}\text { Transformative } \\
\text { capacities }\end{array}$ \\
\hline Response to risk & Ex-post & Ex-ante & Ex-ante \\
\hline Temporal scope & short-term & long-term & long-term \\
\hline Degree of change & low, status quo & medium, incremental change & high, radical change \\
\hline Outcome & $\begin{array}{l}\text { restoration of present } \\
\text { level of well-being }\end{array}$ & security of future well- being & $\begin{array}{l}\text { enhancement of present } \\
\text { and future well-being }\end{array}$ \\
\hline
\end{tabular}

Source: Keck (2012), Lorenz (2010), Obrist et al. (2011), Béné et al. (2012), Keck (2012), Keck and Sakdapolrak (2013)

Coping capacities comprise reactive (ex post) and absorptive types (Béné et al., 2012); they appear when individuals cope with threats and seek to return to a previous state following a critical event. Adaptive capacities consist of proactive (ex ante) (Obrist et al., 2011) or preventive measures (Béné et al., 2012); they describe people who have learned from past experiences, anticipate future risks, and adjust their lives accordingly. Transformative (or participative) constitute individuals' ability to access assets and assistance from a wider sociopolitical context to participate in decision making toward improving their individual welfare and promoting social strength in dealing with future crises (Voss, 2008; Lorenz, 2010).

There are many ways to recover communities resilience. In the case of fishing communities after the shock and stress of the tsunami, they had to rebuild their fishing livelihoods and also enhance their resilience in dealing with such challenges as climate change. Obrist et al. (2011) observed that resilience thinking is implicit in the sustainable livelihood approach: five livelihood assets (social, human, physical, economic and natural capital) play a crucial role in building resilience.

Institutional support is needed to enhance communities resilience. Adger (2000) found that as formal government structures, institutions incorporate the behavior, rules, and norms that govern society; formal institutions are also concerned with membership and the welfare of constituencies and stakeholders. Thus, indigenous institutions have to maintain the resources related to regulating and rehabilitating natural resources as well as issues related to demographic change. Pomeroy et al. (2006) found that indigenous institutions, such as Panglima Laot Lhok (fishing communities' leaders), are involved in fisheries resource management: following the December 2004 tsunami, they helped provide coordination, leadership, and social support and assisted in controlling migration. Indigenous institutions have to enhance local knowledge in the face of natural disasters: they can support local communities in preparedness before a disaster strikes (Adger et al., 2005). Imran and Yamao (2012) found that indigenous institutions 
played an important role in the recovery of social resilience in Krueng Raya Bay, Aceh Besar District (Figure 2).

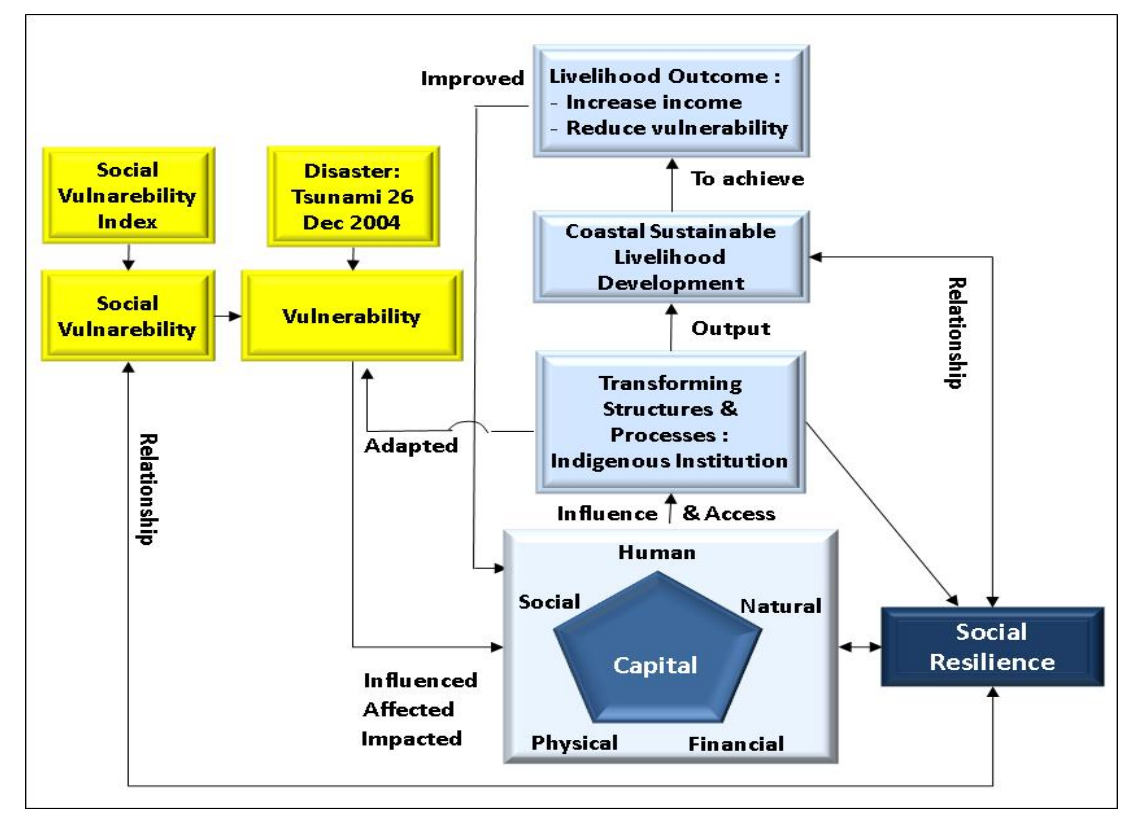

Figure 2. Impact of the Indian Ocean earthquake 2004 on Social Vulnerability, Capital, and Social Resilience. Source: Imran and Yamao (2012a)

Among fishing communities in the aftermath of a huge tsunami, different findings have been reported by researchers. The Tohoku earthquake and tsunami (Great East Japan Earthquake) of March 11, 2011 claimed over 15,000 lives. In the recovery process, local female residents undertook intensive rural life improvement activities based on mutual support at the community level. Those activities have continued as part of community development efforts (Tatsumi et al. 2014).

In light of the above findings, the present study examines women's empowerment as community members with respect to earthquake reconstruction. Section 3 of this paper presents case studies related to the women's recovery processes: it examines how female victims developed social relations as well as how they were encouraged and developed self-confidence and independence. Section 3.1. analyzes some cases related to women's recovery, including disempowerment stories in two villages- $\mathrm{M}$ and $\mathrm{L}$. Section 3.2. focuses on an informal mutual support system related to indigenous institutions (Panglima Laot Lhok, Toke Bangku, and a fish processing association) in village $M$ in Krueng Raya Bay. In section 4, the importance of community-based mutual support systems is underlined with regard to sustainable community development.

\section{Method}

This analysis was based on a literature review and information from secondary data as well as from fieldwork. The literature review included statistical materials, published documents, essays, and other administrative documents of community development and 
recovery process from major disasters in Asia. The fieldwork was conducted in Aceh Province in 2006 (September), 2009 (March, December), 2012 (September), and 2018 (March, August).
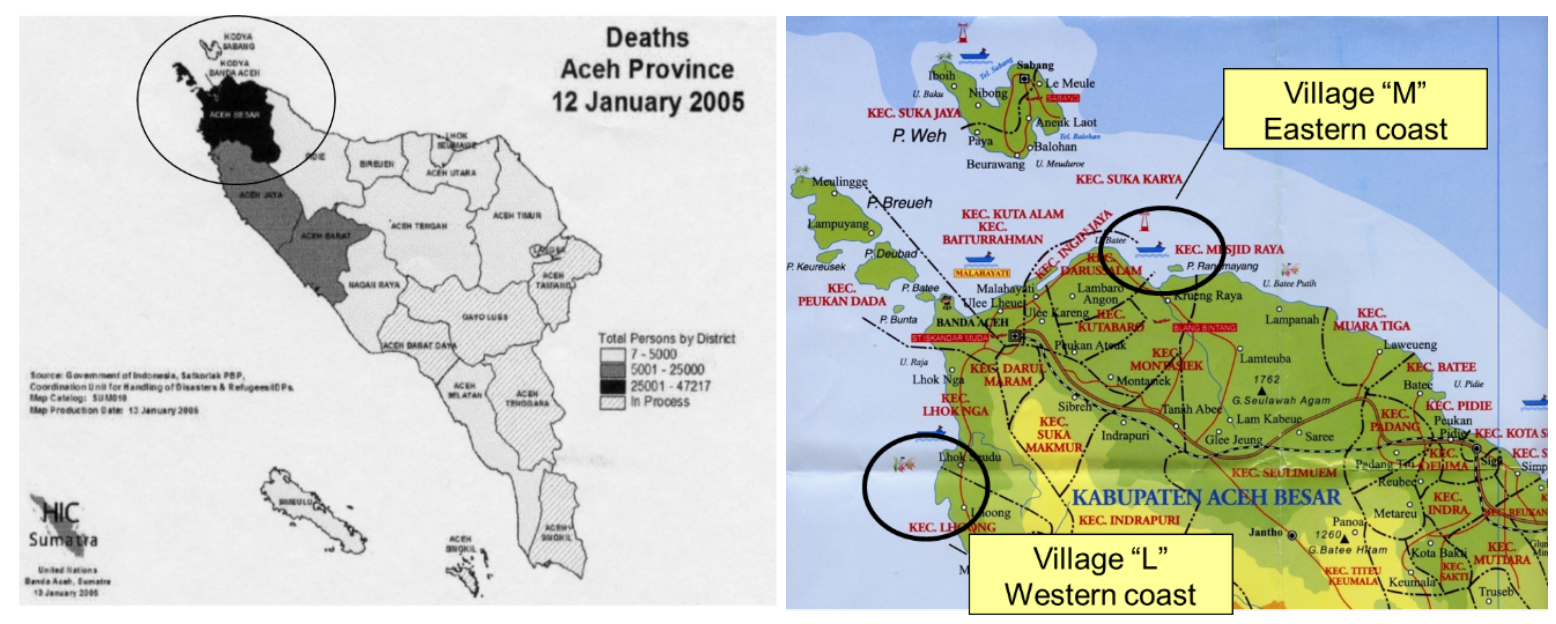

Figure 3. Study Areas in Aceh Province

In 2006, the authors visited several coastal villages located in Mesjid Raya and Leupung sub-districts and Aceh Besar District. In 2009, we selected village $M$ in Krueng Raya Bay on the eastern coast of Sumatra and village L from Layeun region on the western coast in Aceh Besar District. Village M was the target of more projectsfrom donors on the eastern coast, where access is easier; village L was the target of fewer projects - from donors on the western coast, where access is more difficult. The authors conducted key informant interviews to gain information about how women recovered their livelihoods within the disaster management framework. This study emphasizes the importance of listening to what the women had to say: their viewpoint is often overlooked when a macro-perspective is adopted.

With respect to the 2004 Indian Ocean earthquake, we have shifted our research area from women's situation in their households to women's empowerment in community development since 2018. Because it is over fifteen years after the tsunami disaster, their reconstruction efforts can be regarded as sustainable community development. Local systems in most villages were collapse as a result of the tsunami disaster. Village $M$ attempted to improve its livelihood through mutual support. The total population before the tsunami had been around 723 households. Their ninety percent were impacted by the disaster. In village $M$ in the present study, the interviews (conducted in March and August 2018) focused on women's life histories toward understanding how they rebuilt their livelihoods and how communities supported them. The present study used descriptive statistics to convey both qualitative and quantitative data

The present research faced some constraints, including time and budget limits and difficulties in obtaining complete, accurate information from women who were subjected to severe trauma. The fieldwork took 1 week for each village. This study has some limitations, but we attempted to tackle the various issues using our experience in this subject area. The first author has undertaken studies of Japanese women in rural 
community development. After the Tohoku earthquake and tsunami in 2011, she began researching women's activities in terms of the recovery process and made a comparison between the post-disaster situation in Japan and Indonesia (Tatsumi et al. 2014). The second author is Acehnese and specializes in Indonesian fisheries. After the 2004 Indian Ocean earthquake and tsunami, he was responsible for planning and implementing community development and livelihood activity projects in Aceh Besar under the United Nations Development Program (Imran 2010). The third author specializes in coastal resource management in Southeast Asia as well as fisheries and food trade; he is a supervisor of the first two authors.

\section{Results and Discussion}

\subsection{Case Studies of Women's Activities in Villages $M$ and $L$}

This section focuses on women's roles in income-generating activities, such as fisheries processing, store business, and vending snacks, in villages $M$ and $L$. It examines such activities in terms of empowerment and disempowerment, how the women created social networks, and how they experienced self-confidence and independence.

Table 2. Characteristics and Activities of the Study Participants

\begin{tabular}{|c|c|c|c|c|c|c|c|c|}
\hline C ase & V illage & Age & Fam ily $\mathrm{m}$ em bers & Education & Econom ic Activities & Husband's 0 ccupation & Support by donors & $\begin{array}{c}\text { Priority } \\
\text { Relationsh ip } \\
\end{array}$ \\
\hline (1) & M & 27 & $\begin{array}{l}\text { Husband (rem arried), } 2 \text { children, } \\
\mathrm{S} \text { ister's fam ily stay near her } \\
\text { house. }\end{array}$ & $\begin{array}{c}\text { E lem entary school } \\
\text { (graduated) }\end{array}$ & $\begin{array}{l}\mathrm{F} \text { ish process ing and } \\
\mathrm{m} \text { arketing/G rocery } \\
\text { shop/N ew } \\
\text { bus iness b lueberry) }\end{array}$ & laborer works & $\begin{array}{l}\text { House, T ran ing for fish } \\
\text { process ing and } \mathrm{m} \text { arketing, } \\
\text { Process ing too ls, F inance (G } 0, \\
\text { UND P, R otary C lub) }\end{array}$ & $\begin{array}{l}\text { Fam ily, } \\
\text { Relative }\end{array}$ \\
\hline (2) & L & 33 & Husband, 3 children & $\begin{array}{c}\text { E lem entary school } \\
\text { (dropped out) }\end{array}$ & G rocery shop & \begin{tabular}{|l} 
Trader of fisheries \\
bus iness
\end{tabular} & House & $\begin{array}{l}\text { Fam ily, } \\
\text { Re lative }\end{array}$ \\
\hline (3) & L & 28 & Husband, 1 children & $\begin{array}{c}\text { College } \\
\text { (graduated) }\end{array}$ & $\begin{array}{l}\text { Teacher(tem porary)/ } \\
\text { Sell snacks (not daily) }\end{array}$ & 0 wner of $B$ agan & House & $\begin{array}{c}\text { Friend, Fam ily } \\
\text { Re lative }\end{array}$ \\
\hline (4) & L & 49 & Husband, 5 children & $\begin{array}{l}\text { Junior high school } \\
\text { (graduated) }\end{array}$ & $\begin{array}{l}\mathrm{F} \text { ish process ing and } \\
\mathrm{m} \text { arketing/G rocery } \\
\text { shop }\end{array}$ & G rocery shop & $\begin{array}{l}\text { House, Tran ing for fish } \\
\text { processing and } m \text { arketing, } \\
\text { Processing too is (G } 0 \text { \& FA0) }\end{array}$ & Independent \\
\hline (5) & M & 49 & Husband, 5 children & $\begin{array}{c}\text { Junior high school } \\
\text { (graduated) }\end{array}$ & $\begin{array}{l}F \text { ish process ing and } \\
m \text { arketing }\end{array}$ & $\begin{array}{l}F \text { ish process ing and } \\
m \text { arketing }\end{array}$ & $\begin{array}{l}\text { House, Tran ing for fish } \\
\text { process ing and m arketing, } \\
\text { Process ing too ls, F inance (G0, } \\
\text { W orld V is ion) }\end{array}$ & $\begin{array}{l}\text { Fam ily, } \\
\text { Re lative, } \\
\text { Friend }\end{array}$ \\
\hline (6) & L & 29 & $\begin{array}{l}\text { Husband, } 1 \text { children, } M \text { other, } \\
\text { Sister's fam ily stay near her } \\
\text { house. }\end{array}$ & $\begin{array}{l}\mathrm{H} \text { igh school } \\
\text { (dropped out) }\end{array}$ & Sell snacks & $\begin{array}{l}\text { C rew of B agan ship Her } \\
\text { sister's husband is his } \\
\text { capta in) }\end{array}$ & House & $\begin{array}{l}\text { Fam ily, } \\
\text { Relative }\end{array}$ \\
\hline (7) & L & 47 & Husband, 5 children & - & $\begin{array}{l}F \text { ish process ing and } \\
m \text { arketing }\end{array}$ & $\begin{array}{l}\mathrm{F} \text { ish process ing and } \\
\mathrm{m} \text { arketing }\end{array}$ & $\begin{array}{l}\text { House, Train ing for fish } \\
\text { processing and marketing, } \\
\text { Processing too is (GO \& FAO) }\end{array}$ & $\begin{array}{l}\text { Fam ily, } \\
\text { Relative }\end{array}$ \\
\hline (8) & L & 43 & Husband, 5 children & $\begin{array}{c}\text { E lem entary school } \\
\text { (graduated) }\end{array}$ & $\begin{array}{l}\mathrm{F} \text { ish process ing and } \\
\mathrm{m} \text { arketing/Sell snacks }\end{array}$ & $\begin{array}{l}F \text { ish process ing and } \\
m \text { arketing }\end{array}$ & $\begin{array}{l}\text { House, Train ing for fish } \\
\text { process ing and m arketing, } \\
\text { Processing too is (GO \& FAO) }\end{array}$ & $\begin{array}{l}\text { Fam ily, } \\
\text { Re lative }\end{array}$ \\
\hline (9) & L & 26 & $\begin{array}{l}\text { Husband he worked and lived } \\
\text { separate from her in B anda } \\
\text { A ceh), } 1 \text { children }\end{array}$ & $\begin{array}{c}\text { E lem entary school } \\
\text { (dropped out) }\end{array}$ & $\begin{array}{l}\text { House w ife } \\
\text { debt -laden house) }\end{array}$ & $\begin{array}{l}\text { em p byee in a shoes } \\
\text { shop of } B \text { anda } A \text { ceh }\end{array}$ & House & $\begin{array}{l}\text { Fam ily } \\
\text { (lsolated) }\end{array}$ \\
\hline (10) & L & 25 & Husband, 1 children & $\begin{array}{c}\text { E lem entary school } \\
\text { (graduated) }\end{array}$ & $\begin{array}{l}\text { House w ife } \\
\text { \$he is not fine) }\end{array}$ & C rew & $\begin{array}{l}\text { Her fam ily couldn't get a house, } \\
\text { because she stayed in a } \\
\text { refugee cam p when donor cam e } \\
\text { to L village. }\end{array}$ & $\begin{array}{l}\text { Fam ily } \\
\text { (Isolated) }\end{array}$ \\
\hline (11) & Near $L$ & 45 & Husband, 8 children & - & $\begin{array}{l}F \text { ish processing and } \\
m \text { arketing }\end{array}$ & C apta in of sm all boat & House & $\begin{array}{l}\text { Fam ily, } \\
\text { Relative }\end{array}$ \\
\hline (12) & Near $L$ & 63 & $\begin{array}{l}\text { W idow (one daughter stays near } \\
\text { her house) }\end{array}$ & $\begin{array}{c}\text { E lem entary school } \\
\text { (graduated) }\end{array}$ & $\begin{array}{l}\mathrm{F} \text { ish process ing and } \\
\mathrm{m} \text { arketing/G rocery } \\
\text { shop }\end{array}$ & - & House & $\begin{array}{l}\text { Fam ily, } \\
\text { Re lative }\end{array}$ \\
\hline (13) & Near L & 31 & $\begin{array}{l}\text { Husband, } 2 \text { children (Stay near } \\
\text { her mother (case 12)) }\end{array}$ & $\begin{array}{l}\text { Junior } h \text { igh school } \\
\text { (graduated) }\end{array}$ & $\begin{array}{l}\text { F ish process ing and } \\
m \text { arketing/G rocery } \\
\text { shop }\end{array}$ & C apta in of sm a ll boat & House & $\begin{array}{l}\text { Fam ily, } \\
\text { Relative }\end{array}$ \\
\hline
\end{tabular}

Source: Field Survey (2009) 
Table 2 presents the characteristics and activities of the thirteen women in villages $M$ (15.38\%) and L (84.62\%) who participated in our field survey in 2009. In 2012 and 2018, the authors followed up on the subsequent changes those participants had undergone. There were eleven successful and two unsuccessful cases of empowerment: cases 1-8 and 11-13 reflect an empowerment process through social relationships; cases 9 and 10 represent disempowerment stories. Incidentally, the average income of fishermen was 150 US dollar/month in 2004 in Aceh Province, in national level was around 200 US dollar/month. 1 US dollar is equal 9,244 rupiah on 31 December 2004 (Bank Indonesia).

\subsubsection{Empowerment Cases}

\subsubsection{Case 1 in Village $M$}

Case 1 was a woman engaged in the family business of fish processing and marketing as well as operating a grocery store. She started to grow blueberries. She and her father, mother, elder sister (living near her house), and younger brother (also living nearby) engaged in fish processing. As a trader, her father collected fish, and the other family members boiled and dried them. The United Nations Development Program (UNDP) supported half the costs in building the family's processing facility and the Rotary Club gave case 1 an interest-free loan of around 2 million rupiah to develop the business between 2005 and 2007. With amount of money, she bought 100 nets for drying fish. She paid back the first loan and received a new business loan of 2 million rupiah.

Before the tsunami, she was divorced from her former husband. She obtained custody of their son. After the tsunami, she remarried and delivered birth for a second son. Following the disaster, she decided to pursue her business independently, with her family providing emotional and socioeconomic support. At the time of the last interview, her second husband worked as a laborer, earning 50,000 rupiah a day. Her daily income then was 10,000 rupiah from the store and 50,000-100,000 rupiah from the fish processing unit (FPU). Her income was thus higher than her husband's. She played a vital role in the life of her extended family. She did not participate in any group support activities because the relationships within her family (especially with her elder sister) were very strong.

Case 1 was empowered through generating income and home industry family cohesion. In 2012, she stated, "It's important for people to improve their family's livelihood by themselves because eventually support projects come to an end." She was one of the few participants to free herself from over-dependency on outside support; she was one of a number of participants who had no interest in community development.

\subsubsection{Case 2 in Village $L$}

Case 2 had given birth to a third child by the time of the tsunami, so she needed financial support for her new baby and for education for her first two children. She opened a grocery store in 2009 at the front of her house. At the time of the last interview, she was making a daily profit of 20,000 rupiah on a turnover of 100,000 rupiah. Her husband worked as a trader, earning 10,000-50,000 rupiah a day. Once a week, she and her husband together went wholesale shopping in Banda Aceh (capital city of Aceh Province). 
When opening her store, she did not receive any financial support except for housing assistance. She borrowed 5 million rupiah from a cooperative (micro-finance institution) to provide her the investment capital from a financial group. The financial group was a rotating saving and credit association (ROSCA). ROSCAs comprise groups of individuals who meet for a defined period of time to save and borrow together. In Indonesia, ROSCAs play an important role both as savings institutions and as mutualhelp societies operating under a peer-monitoring mechanism. ROSCAs typically collect 200,000 rupiah from each member every month. One person, selected by lot, can receive a total amount of 2 million rupiah.

Case 2 participates in a WIRIT. A WIRIT is a women's religious group in a village: they recite The Holy Qur'an and Prophet Muhammad's blessing. WIRIT is hold in masques or meunasah organizing (villager's places for prayer). The social activities of the WIRIT for case 2 were spending time together eating snacks, drinking beverages, exchanging information, and supporting one another every Thursday. Case 2 had social networks inside and outside the community. She felt that the relationship with her family and relatives was stronger than the relationship with the WIRIT.

\subsubsection{Case 3 in Village $L$}

Case 3 was a woman who had the potential to become a social leader even though she was still young. At the time of the last interview, she was an elementary school teacher: her monthly salary was only 200,000 rupiah owing to her post having been temporary. She wanted to contribute to her community, so she also undertook volunteer work. When she was last interviewed, she had just opened a small store at the front of her house to sell snacks and cakes to locals. She made a profit of 5,000 rupiah on a turnover of 20,000 rupiah a day. The shop was not open daily because of her volunteer work.

Her husband was the owner of a lift net boat (bagan). His daily income was 100,000-500,000 rupiah and it depend on season. At the time of the last interview, the husband was suffering from a mental condition (trauma) due to the death of his father, previous wife, son and daughter in the tsunami. He remarried with women in case 3 , and they had a baby. His condition was beginning to improve at the time of interview through his wife's support. Case 3 had two close friends, who were neighbors. Every day, she was able to share her happiness and problems with those friends.

\subsubsection{Case 4 in Village $L$}

At the time of the 2009 interview, case 4 had opened her grocery store and started a fish-processing business seventeen years earlier. When she married her husband 30 years ago, he was a laborer, and his income was low. When case 4 opened her small store, she had only a few customers. So she began a door-to-door delivery service for the local community using her bicycle. As a result, local residents became familiar with her store and her business manner, and they started trusting her. Through her business, she established a social network. Through that experience, she built up self-confidence and networking costumer of her mobile market business.

At the time of the last interview, her daily income from the store was 50,000100,000 rupiah. When the tsunami struck, she was fortunate in that all her family members remained physically fine, but she lost her store, two houses, and processing 
facilities. She received housing assistance from one donor. Rebuilding her store called for 50 million rupiah: she used her savings and borrowed 3 million rupiah from friends as working capital.

Case 4 stated in her last interview that she considered good neighbors to be better than distant relatives. She wanted to participate in local group activities, but no groups existed at the time. She was an independent person and a leader among local women. Case 4 served as a point of entry for donors wanting to provide assistance to village L. Case 3, the younger woman's leader, relied very much on case 4 . By the time of the field survey in 2012, case 4 had died.

\subsubsection{Case 5 in Village $M$}

Case 5 worked for the family business of fish processing and marketing. She belonged to a women's group with close connections to fish processing. At the time of the last interview, her group consisted of three members; since 2005, it was supported by the program Medical Emergency Rescue Committee of World Vision (Christian relief, development, and advocacy organization). A Chinese business man provided marketing support for the family business.

\subsubsection{Case 6 in Village L}

Case 6 was a woman who lived with her husband, daughter, and mother. Her sister's family lived next door. Her husband worked as a crewman on a bagan, captained by her brother-in-law. The two families had a close relationship. The household income of case 6 was 150,000-200,000 rupiah per week. She contributed $25 \%$ of that income. According to the need for more money for child care following the tsunami, she began a business selling snacks.

\subsubsection{Cases 7 and 8 in Village $L$}

Cases 7 and 8 worked for family businesses involved in fish processing and marketing. They were close friends of case 4 . Cases 7 and 8 provided nets for drying the fish of the food and agriculture organization.

\subsubsection{Case 11 near Village L}

Case 11 worked in fish processing and marketing and was assisted by her daughters and grandchildren. Her husband operated a small boat. His income was 15,000-150,000 rupiah a day. She did not belong to any social or business group and did not has anywhere to undertake fish processing independently. She supplied nets for drying fish. She sold dried fish on the roadside near her home. Her income depended on the amount of traffic passing by and season.

\subsubsection{Cases 12 and 13 near Village $L$}

Case 12 was living alone: her husband left her before the tsunami struck. Case 13 lived close to her daughter, who resided near her mother's house with her husband and children. Both case 13 and her daughter worked in fish processing and marketing, and they also ran stores: they helped each other on a daily basis. 


\subsubsection{Disempowerment Cases}

\subsubsection{Case 9 in Village $L$}

Case 9 was one of two close friends of case 3. Case 9 also had an additional good friend, with whom she shared her happiness and problems. Case 9, case 3, and case 9's friend enjoyed good mutual support emotionally and socially; however, there was no financial support among the three of them.

The husband of case 9 was an employee in a small shoe store in Banda Aceh. He borrowed 20 million rupiah from a bank to start a new business between 2007 and 2008, but the business failed. He was able to repay 14 million rupiah, but he could not repay the remaining 6 million rupiah. That resulted in a bank official going to the family home, demanding repayment. One of the husband's friends helped him by lending him a motorcycle. The banker took the motorcycle as surety. However, the husband's financial situation did not improve, and he was unable to pay for the return of the motorcycle. That incurred the anger of the husband's friend, who went to the family home and confiscated their television and furniture by way of payment. Because of the financial problems, the friendship between her husband and his friend collapsed.

Case 9 was still worried about money at the time of the last interview. Even though she had good relationships with her friends, it is not easy for her to borrow much money. At the time of the last interview, she did not a job and any idea about how to raise income. If there had been the possibility of microfinance groups, her situation would have been better. There is a particular needs for microfinance groups in village L: they offer an integrated approach, including motivation, skill training, information exchange, and sharing of common interests.

In 2012, case 9 and her family moved out of village L. She moved with her child to Banda Aceh, where her husband was employed in a shoes store.

\subsubsection{Case 10 in Village $L$}

Case 10 had suffered from trauma as a result of the tsunami struck. She stated that after the disaster, she lost a lot of weight. At the time of the last interview, she declared that she was an insomniac and prone to headaches. She said that after the tsunami, she had physically made a $75 \%$ recovery but that her mental condition aspect had only partly recovered. She was unlucky because she had not been able to obtain free housing from a donor agency. At the time of the last interview, it had become too late for her to qualify for free housing. Accordingly, she had to pay 70,000 rupiah a month in rent.

Following the tsunami, she stayed in a refugee camp for 6 months and then in postdisaster accommodation for 2 years. There, she met a fisherman, married him, and subsequently returned to village L. Her husband worked as crew on a fishing boat and earned only 200,000 rupiah per week. Case 10 was worried about both her mental condition and about money problems. She had hoped to open a tearoom, but she was not working at the time of the last interview and had no means of generating income. In 2012, she and her family moved out of village L. It was not known where she had moved to.

\subsubsection{Inferences from the Case Studies}

It was clear that a number of projects had been implemented in village $\mathrm{M}$. With case 1 , the woman was empowered through income-generating activities and strong family 
cohesion. By contrast, few projects - except for housing assistance-were implemented in village L. Residents in village $\mathrm{L}$ were unable to receive much donor support. Village $\mathrm{L}$ residents naturally expected some aid of donor assistance because they were aware of the situation in village $M$. Thus, village $L$ residents tried to improve their situation by developing social relationships among family, relatives, and friends.

There were evident differences between rich and poor and between active and passive residents in the two villages. Individuals who had undergone disempowerment (cases 9 and 10) needed greater outside support to escape the vicious cycle in which they found themselves. Cases 3 and 4 wished to participate in group activities, but there were no opportunities for them to do so. Thus, in areas were badly affected by the disaster, where all livelihood assets had been completely destroyed, medium- to longterm livelihood programs should have been implemented.

Projects introduced by donor agencies have limitations, but emergency support is necessary. It is crucial that projects be implemented at the right time and in the right place. From a middle- and long-term perspective, income-generating and microfinance projects are effective in helping disaster victims retain their livelihoods by themselves. Local leaders should play an important role by coordinating donor agencies in the selection of appropriate places for restoration. For reconstruction and sustainable community development, that process should involve both local and formal institutions. Village L lacked indigenous institutions and mutual support at the community level. That village was one of the coastal communities that suffered most in the tsunami. The disaster may have exerted a negative impact on the social system through the accumulated damage to fisheries facilities and livelihoods.

There was, however, also evidence concerning excessive reliance on externally funded projects. When the projects came to an end, most of them were permanently closed due to lack of sustainable funding on the part of implementing agencies. Accordingly, the following section presents an indigenous institution and mutual support in village $M$.

\subsection{Focus on Community-Based Activities in Village $M$ \\ 3.2.1. Life History of Case 1 in Village $M$}

This section focuses on case 1 toward determining how women in the disaster area rebuilt their livelihoods and how communities supported them. Most of the information presented here was obtained from a field survey that took place in 2018.

Case 1 became empowered through income-generating activities and strong family cohesion. By the time of the 2018 interview, most externally funded projects had come to an end. She realized that it was incumbent on her to improve her family's livelihood. Case 1 was one of the few individuals interview to overcome dependency on external funding.

In 2015, her husband died of a disease, and she became a young widow. At that time, she was aged 31 years: she had a son (aged 15 years), daughter (aged 7 years), and another son (aged 18 months). She closed her grocery store. Her mother was old and not well, but her father worked as a boat builder and in fish processing and was a former fishermen. Case 1 had a strong relationship with her elder sister. Her brother-in-law has worked for Panglima Laot Lhok since 2017. After closing her grocery store, she was employed by her father. Her family's income was 1-2 million rupiah a month through 
fish processing and 3 million rupiah a year from agriculture (growing ginger and chilies). Case 1 was able to obtain 300,000 rupiah a year from the community fund and selling fresh fish in the community fish market or small auxiliary market (Tempat Pelelangan Ikan, [TPI]) in the early morning. She concentrated on fish processing and felt confidence in conducting that business. Case 1 stated that in the near future, she wanted to become independent of her father. She believed that family support alone was insufficient. Mutual support at the community level had become increasingly important for her. Case 1 received support from her family, relatives, and the community.

This case suggests that income generation through fish processing and mutual support from the family, relatives, and community would be most effective for individual empowerment. Business links based on personal trust are necessary for this process to work smoothly. One aspect of networking is that a ripple effect is produced with other networks.

\subsubsection{Local Leaders in Village $M$}

In Village M, local residents depend heavily on fisheries and are engaged in various fisheries activities. In particular, anchovy fisheries and related businesses have developed rapidly: village $M$ is one of four places that constitute the center of anchovy fisheries in Aceh Besar District. One traditional means of managing coastal resources exists in the form of Panglima Laot Lhok.

Imran and Yamao (2012) identified the important roles of Panglima Laot Lhok, Toke Bangku (financial traders), fish processing association, Mosque Family Board, and traditional culture groups (dalail) in community development at the local level. The present study found that women's community-based activities in village $M$ were Panglima Laot Lhok, Toke Bangku, and the fish processing association. They play a significant role in strengthening women's involvement in livelihood recovery.

\subsubsection{Panglima Laot Lhok}

Panglima Laot Lhok is a system for guiding the local fishing community as well as resolving conflicts and disputes among fishermen; it is responsible for determining improper practices in fishing activities, and it imposes penalties against violators (Nurasa et al. 1993). After the disaster, Panglima Laot Lhok was involved in the recovery of fishing communities, and it facilitated the delivery of aid to fishermen. Panglima Laot Lhok has access to the Fisheries Office at the district and provincial level as well as to donors. Through Panglima Laot Lhok, a system has been established between fishermen and customers, and it has led to the expansion of social networks. Most villagers as fishermen have a trust to the Panglima Laot Lhok leader. According to the rules of Panglima Laot Lhok, it should provide money or goods to widows, and funding is available. Moreover, widows in village $M$ can receive 300,000 rupiah a year from the community fund.

\subsubsection{Toke Bangku}

Toke Bangku means "financial traders," and they help support advance payments and market channels. They play a substantial role in the marketing of fish. After fish are landed in village $\mathrm{M}$, they are sold to Toke Bangku, which in turn sells the catch to muge (mobile markets) or other local consumers (Garces et al. 2010). Toke Bangku also plays 
a significant role in enhancing the fisheries livelihood. It is closely related to fishermen, and they are mutually dependent on each other. The relationship between Toke Bangku and fishermen is one of personal bonding, trust, and complementation. In this mutual cooperation, there are no legal commitments. Toke Bangku provides operational funds and maintenance costs to fishermen for fishing, and the fishermen are obliged to sell their catch to Toke Bangku. However, fishermen often borrow money from Toke Bangku to pay for daily goods during the fishing season. If fishermen cannot afford to pay back their loans, Toke Bangku does not insist on collection. Thus, as evident in the 2012 field survey, a strong emotional connection develops between fishermen and Toke Bangku.

Toke Bangku also supports women engaged in fisheries processing. Women usually buy $90 \%$ of their fish from Toke Bangku and 10\% directly from fishermen. At around 6 a.m., men and women await the bagan fishing boats in TPI. There is a competitive buying system after the boats land their catch, but a negotiated system prioritizes women, especially widows. The usual price of one basket (around 20-25 kg) of fresh fish is 400,000-450,000 rupiah. But for women up to 20 baskets, it is 300,000 rupiah (field survey, 2018).

\subsubsection{Fish Processing Association}

The fish processing association was established in September 1995. At the time of the 2018 field survey, the leader (aged 60 years) managed 32 units (one unit comprises three or four members) with 120 members (70\% female). The leader began net fishing in the 1970s. He and his friends established the Toke Bangku system and rules in the 1980s. From 1990 to 1995, he attempted to set up a mobile trader system. He provided a service for developing social networks among fishermen and markets. In January 1990, he started fish processing using his own capital (3.5 million rupiah). His business turned a benefit. In 1990, he rented 120 square meters of land (1 square meter@ 50,000 rupiah/month; 120 square meters $=6$ million rupiah). After 3 years, he brought an additional 200 square meters of land (1 square meter@12,000 rupiah; 200 square meters $=2.4$ million rupiah). From 1993 to 2000, he delivered processed fish to Medan through senior traders. Medan is the largest city in North Sumatra and has big fishery markets. Through a process of trial and error, he sought good traders with whom he could work. In 2000, he found a Chinese trader who was suitable as a partner in Medan. The Chinese trader sometimes made payments in advance. The leader collected and sent the processed fish to Medan; the Chinese trader paid for the fish into the leader's bank account. In turn, the leader made payment to members of the fish processing association.

With the tsunami, the leader lost everything, including the lives of his wife and daughters. He felt lonely and was under considerable pressure and stress for about 6 months. Former members of the association approached him with the request to restart fish processing, but he rejected such advances. A friend then advised him, "Look at woman with a child that she is leading by the hand. Compare yourself with her. You must then ask yourself what exactly you are doing." The leader then had a change of heart. On June 2005, he married his second wife, and his condition improved. In 2005, eight fish-processing units recommenced operation with the support of JRS (nongovernment organization). From 2007 to 2008, Oxfam International and United States 
Agency for International Development (USID) supported additional processing units. In a meeting of the association, the leader asked the members what was necessary and how they could improve their situation. At the meeting, the members (including women) reported their good and bad experiences. Subsequently, the leader made various requests to traders. Sometimes, his associate, the Chinese trader, responded to such requests. The leader did not request a commission for his management role, but the members paid him a small fee.

\subsubsection{Mutual Support in Village $M$}

These cases show that among women, the most important factors in their recovery were as follows: (1) a firm relationship with family and relatives; and (2) strong friendship. In most cases in Aceh Besar, a strong relationship existed with family and relatives. In an emergency, families and relatives have priority. However, beyond the emergency phase, it is important that family and relatives are able to play new roles in community development.

Many victims have gradually recovered since the disaster. As a result of tremendous efforts, people have slowly regained their vitality. Following the tsunami, many couples married, and there was a baby boom. In resettlement communities, newcomers became accepted as community members as wives, husbands, and children. Over fifteen years after the tsunami, reconstruction has shifted to sustainable community development.

For sustainable community development, the roles of local leaders, mutual support, and indigenous institutions are very important. All the residents in village $\mathrm{M}$ are victims and have undergone terrible experiences. They help one another on an individual and social basis. Based on social capital, the indigenous institution of Panglima Laot Lhok has assumed a governing role in this fishing community.

The leader of the fish processing association is a new type of leader, chosen by the association members. There are different kinds of leaders in village $\mathrm{M}$, and each one plays a different role in community development. By having bonded the coastal community through social networks as well as establishing rules, norms, sanctions, and relationships of trust from long before the disaster, community leaders have evolved within both indigenous (or old) and formal (or new) institutions.

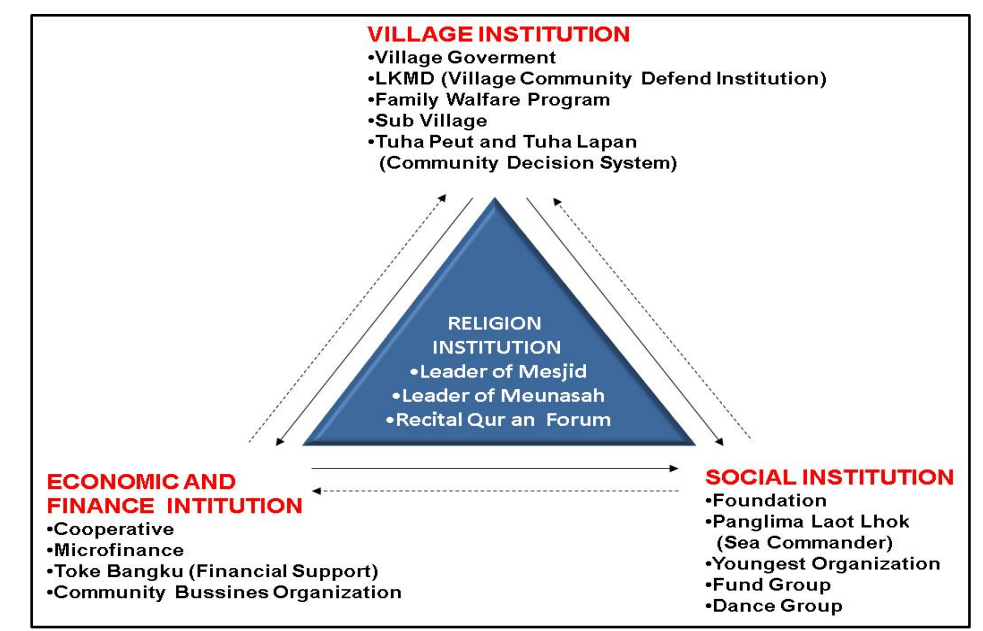

Figure 4. Triangular Relationships among Institutions at the Research Site Source: Imran and Yamao (2012a) 
Community leaders play important roles with respect to both economic and social institutions in village $M$ (Figure 4). Mutual support in the community and indigenous institutions are critical toward strengthening social resilience.

\section{Conclusion}

Most projects directed at the recovery of women following the disaster in Aceh Besar aimed to operate over short periods and were unsustainable. That situation was unavoidable because most funding schemes were designed for short-term projects: the average project duration was under two years. Nowak and Caulfield (2008) suggested that programs for empowering women and promoting their livelihoods should adopt a strength- or asset-based approach, which would encourage women to look beyond their stereotypical gender roles.

From a mid- to long-term perspective, the present study has demonstrated that family- and community-based support is more important than project-based support. Significant factors in the recovery process among the participants in this study were as follows: (1) a firm relationship with family and relatives; and (2) a strong sense of friendship. In most cases in Aceh Besar, strong relationships with families and relatives existed long before the disaster.

Though the patterns of strong relationships and individual situations differed, the mutual support and emotional relations developed after the tsunami served to empower the local women. Further, the women victims gradually developed, increasing their selfconfidence and independence. Ultimately, however, relationships between the women and their families, relatives, and friends are insufficient because all those relationships have their basis in the local community. They were important members of their local communities. With coastal communities in particularly, locals have a strong sense of unity. Their indigenous institutions remained in place and adapted to the situation following the disaster.

As seen in Figure 5, the 2004, the Indian Ocean earthquake exerted a direct impact on the social, human, physical, economic, and natural capital of the fishing communities in Aceh Besar. If parts of that capital collapsed, the fishing communities became subjected to increased social vulnerability and decreased social resilience. However, the present study identified one community (village $M$ ) that coped successfully with the disaster. Following the tsunami, the community needed emergency support from the government and donors. Over fifteen years after the tsunami, that reconstruction may be regarded as having led to sustainable community development. Local residents have improved their livelihoods through community-based activities.

The roles of women expanded as a result of the recovery process following the tsunami. Mutual support and emotional relations helped improve women's empowerment and their activities. Further, women victims gradually came to develop self-confidence and self-dependence. The long-term outcomes have been evident in an increase in women's roles within the social sphere, greater income generation for female-headed households, and better quality of life for all in the community. In turn, women receiving support from their community had a positive effect on relationships with their families, relatives, neighbors, friends, and community after the tsunami.

This study evaluated community-based activities that ensured sustainable development of coastal communities in Aceh Besar. It was found that women could be empowered 
through both family- or relative-based and community-based activities. The key to success in strengthening social resilience after the disaster was the capacity of facilitators in strengthening local institutions, encouraging community involvement at every stage of program management, and building community commitment and local institutions. Other factors were recovery of the fisheries and women livelihoods with respect to growing mutual trust and establishing a boundary for roles between internal and external institutions. Further, local institutions should combine with external ones to assist women in the recovery process.

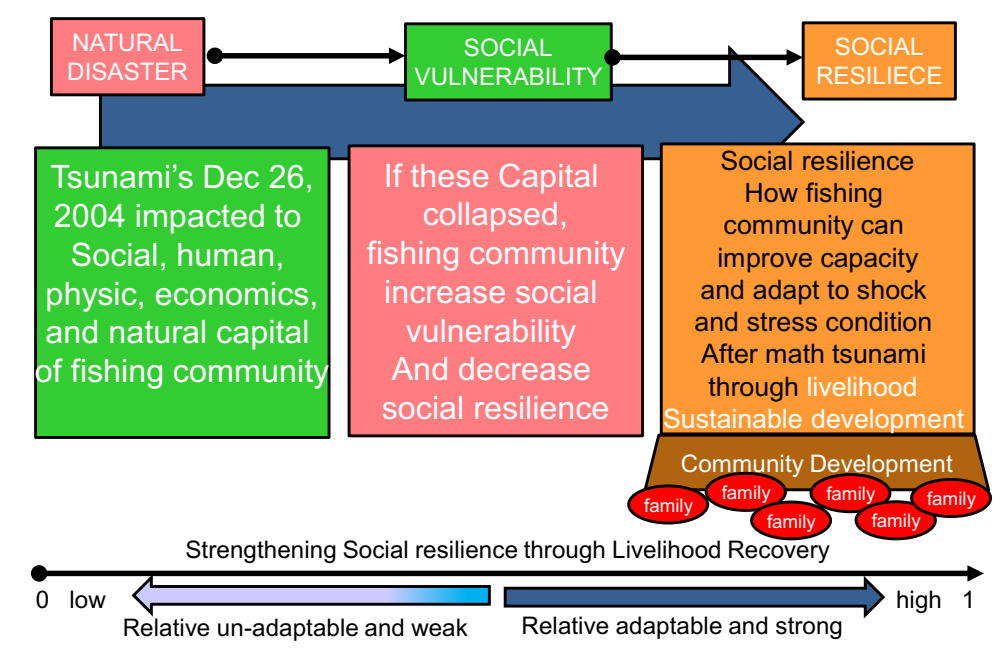

Figure 5. Social Vulnerability and Social Resilience following the Tsunami in Aceh Besar Source: the authors based on Imran and Yamao (2014)

This study focused only on factors related to women in coastal community development. Future research should examine community-driven activities. Sustainable community development involves the shift from community-based to communitydriven activities.

\section{Acknowledgments}

This paper was based on a presentation at the International Seminar of Rural Sociology and Community Development (ISRC2019) on November 21, 2019 in Lombok, Indonesia. The authors appreciate the valuable comments of the participants. The authors would like to express their thanks and appreciation to all friends who participated in this research. This work was supported by JSPS (KAKENHI Grant Numbers JP16H03708 and JP19H01584) and the office for Female Researchers, Fukuoka University. The authors thank the Edanz Group (www.edanzediting.com/ac) for editing a draft of this manuscript. 


\section{References}

Adger, W. N., Hughes, T. P., Folke, C., Carpenter, S. R., \& Rockström, J. (2005). Social-Ecological Resilience to Coastal Disasters. Science (New York, N.Y.), 309(5737), 1036-9.

Adger, W. N. (2000). Social and ecological resilience: are they related? Progress in Human Geography, 24(3): 347-364.

Béné, C., Wood, R. G., Newsham, A., \& Davies, M. (2012). Resilience New Utopia or New Tyranny? Reflection about the Potentials and Limits of the Concept of Resilience in Relation to Vulnerability Reduction Programmes, No. 405, Vol. 2012, Brighton, UK.

BRR NAD-Nias, (2009a). Tsunami from disaster to the emergence of light. Indonesia: BRR NAD-Nias-Multi Donor Fund-UNDP.

BRR NAD-Nias, (2009b). Education, Health and Women Empowerment: Preparing Quality Generation. Indonesia: BRR NAD-Nias-Multi Donor Fund-UNDP.

BRR NAD-Nias, (2009c). Case Study: The Scattered Beads. Indonesia: BRR NADNias-Multi Donor Fund-UNDP.

BRR NAD-Nias and International Partners, (2005), Ache and Nias One Year After the Tsunami: The Recovery Effort and Way Forward, Indonesia: BRR NAD-Nias.

Burke, A., (2005). Current Society and Politics in Aceh: Key Trends, Local Figure, and Other Issues. London, United Kingdom Department for International Development.

Garces, L.R., M.D. Pido, R.S. Pomeroy, S. Koeshendrajana, B.I. Prisantoso, N.A. Fatan, D. Adhuri, T. Raiful, S. Rizal, A. Tewfik, and M. Dey, (2010). Rapid assessment of community needs and fisheries status in tsunami-affected communities in Aceh Province, Indonesia. Ocean and Coastal Management, 53(2): 69-79.

Imran, Z and Masahiro, Y. (2014). Factors Affecting Changes of Fisheries Livelihood 7 Years after the Asian Tsunami in Krueng Raya Bay, Aceh-Indonesia, Journal of Regional Fisheries 54(2):1-24.

Imran, Z and Masahiro, Y. (2012a). Toward Strengthening Social Resilience: A Case Study on Recovery of Capture Fisheries after the Aceh Tsunami, Indonesia, presented at the international conference on Agriculture, Fisheries and Veterinary, Singapore.

Imran, Z and Masahiro, Y. (2012b). Toward Strengthening Social Resilience: A Case Study on Recovery of Capture Fisheries after Asia's Tsunami in Aceh, Indonesia, World Academy of Science, Engineering and Technology 69: 817-827. 
Imran, Z, (2010). Fisheries Livelihood Recovery Program as a Case Study in Krueng Raya Ache Besar District. Developing Social Capital to Replace Foregoing Donors (Yamao ed.), Toyota Foundation Report :125-135.

Jayasuriya, SiSsira and McCawley, P. (2008). Reconstruction after a Major Disaster: Lessons from the Post-Tsunami Experience in Indonesia, Sri Lanka, and Thailand. ADB Institute Working Paper, 125.

Keck, M., \& Sakdapolrak, P. (2013). What is social resilience? Lessons learned and ways forward. Erdkunde, 67(1): 5-19.

Lorenz, D. F. (2010). The diversity of resilience: contributions from a social science perspective. Natural Hazards, 67: 7-24.

MacDonald, R., (2005). How Women were affected by the Tsunami: A Perspective of Oxfam. PloS Medicine, 2: 474-475.

Naamin, and R. Basuki, (1993). The Role of Panglima Laot (Sea Commander) System in Coastal Fisheries Managment in Aceh, Indonesia. in Proc. Twenty Second IPFC Fisheries Symposium, Bangkok: 395-405.

Nowak, B.S. and Tanya, C. (2008), Women and Livelihoods in Post-Tsunami India and Aceh, Asia Research Institute Working Paper, No. 104.

Obrist, B., Pfeiffer, C., \& Henley, R. (2011). Multi-layered Social Resilience: A New Approach in Mitigation Research. In U. Wiesmann \& H. Hurni (Eds.), Research for Sustainable Development: Foundations, Experiences, and Perspectives Edited, Vol. 6, Bern-Switzerland.

Oxfam International, (2005). The Tsunami Impact on Women. Oxfam Briefing Note.

Pomeroy, R. S., Ratner, B. D., Hall, S. J., Pimoljinda, J., \& Vivekanandan, V. (2006). Coping with disaster: Rehabilitating coastal livelihoods and communities. Marine Policy, 30: 786-793.

Silverman, Robert Mark. eds. (2004). Community Based Organizations. Detroit: Wayne State University Press.

Tatsumi, K., Yamao, M., and Imran, Z. (2014). The roles of Women in the Recovery of Tsunami: Affected Coastal Communities, A Comparative Study between the Aceh Province of Indonesia and the Tohoku Region of Japan. KFAW Working Paper, 2013-1, in Japanese.

Tatsumi, K. (2010). Self-Dependence and Role of Social Networks: Women's roles in Reconstruction. Developing Social Capital to Replace Foregoing Donors (Yamao ed.), Toyota Foundation Report :136-145. 
Tobin, G. A. (1999). Sustainability and community resilience: the holy grail of hazards planning? Environmental Hazards, 1: 13-25.

Voss, M. (2008). The vulnerable can't speak. An integrative vulnerability approach to disaster and climate change research 1. A Journal on Civilisation, 3: 39-56.

Women Study Center-IAIN Ar-Raniry, (2005). Gender and Change in TsunamiAffected Villages in Nanggroe Aceh Darussalam Province. Research Report, UNFPA and Oxfam. Indonesia.

Yamao, M (ed.) (2011). Developing Social Capital to Replace Foregoing Donors: A Study on the changes in the structure and functioning of coastal communities of Sri Lanka, Thailand, and Indonesia in post-tsunami period. Toyota Foundation Report.6, 2016, from www.doleta.gov/agworker/news.cfm. 